Neurolmages
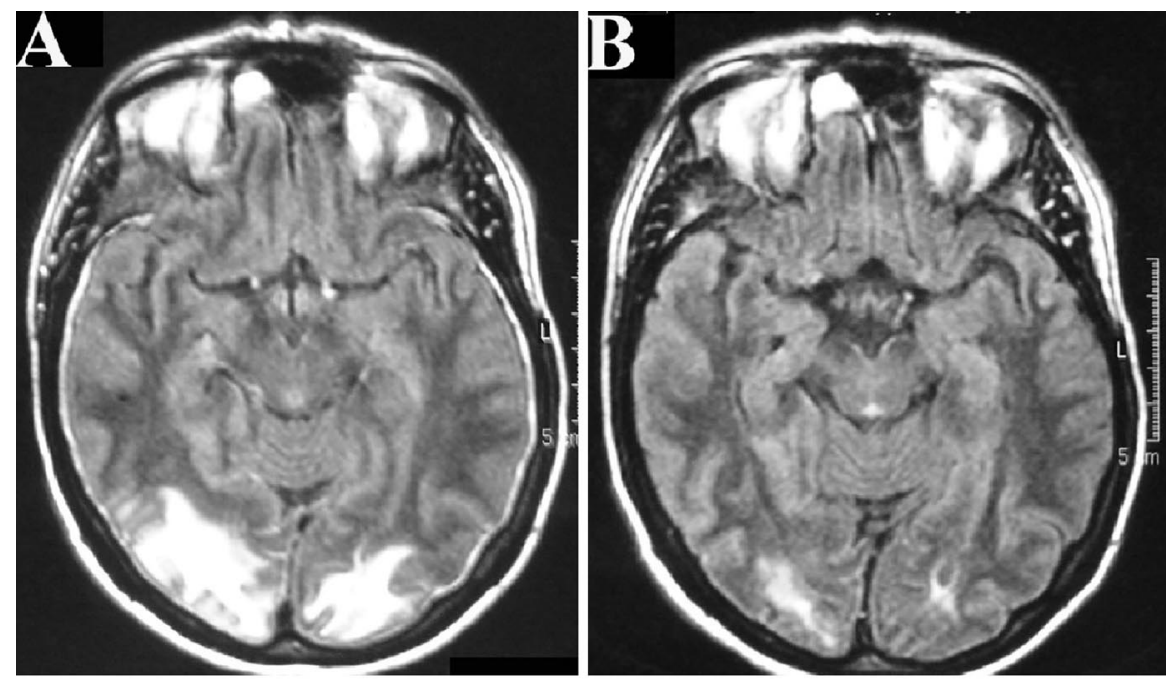

Figure. Brain MRI with fluid-

attenuated inversion recovery (FLAIR) $(A, B)$ and diffusion-weighted imaging (DWI) $(C, D)$ sequences showing an initial (A, C) bilateral cortico-subcortical occipital high signal intensity with in-
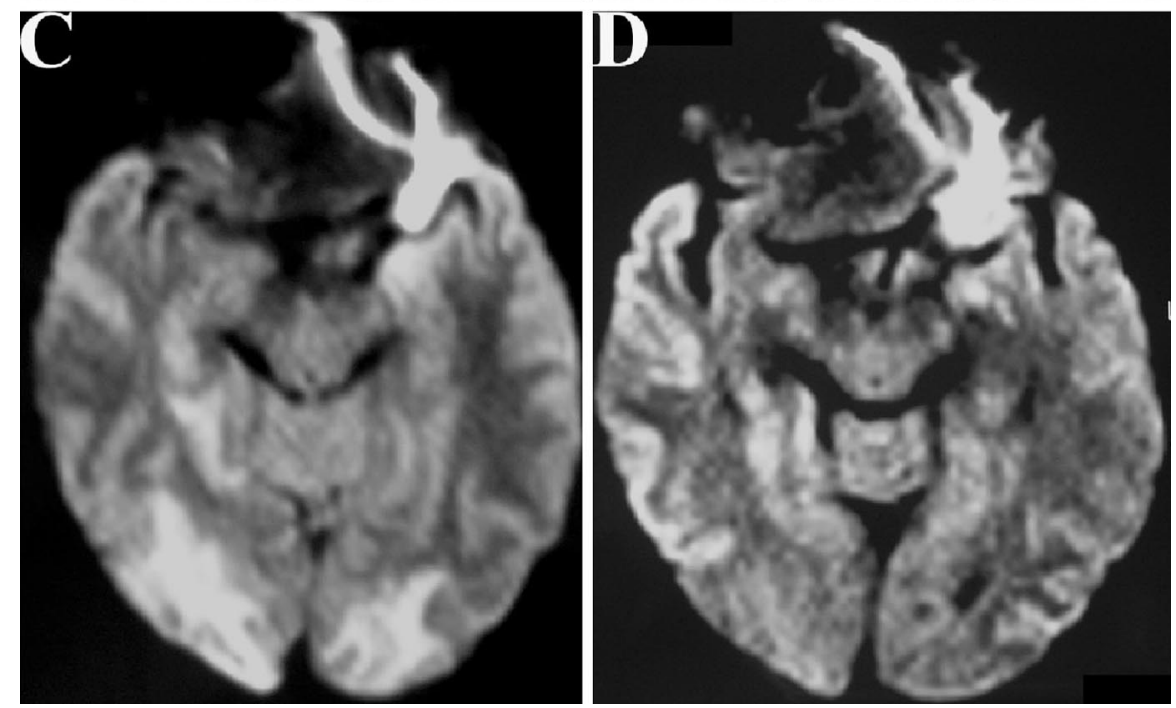
creased apparent diffusion coefficients $(A D C)$. Two weeks later $(B, D)$ there is a decreased in FLAIR and DWI abnormalities and an $A D C$ normalization suggesting radiologic regressive posterior leukoencephalopathy.

\section{Creutzfeldt-Jakob disease mimicking radiologic posterior reversible leukoencephalopathy}

I. Sibon, MD, PhD; A. Foubert, MD; P. Menegon, MD;

F. Yekhlef, MD; V. Dousset, MD, PhD; and J.M. Orgogozo, MD, Bordeaux, France

A 51-year-old woman was admitted with progressive blindness, cerebellar syndrome, myoclonia, and frontal dementia which developed over 2 months. EEG showed a pseudo-periodic activity,

Address correspondence and reprint requests to Dr. I. Sibon, Service de Neurologie A, Hopital Pellegrin, Place Amélie Raba-Léon, 33076 Bordeaux cedex, France; e-mail: igor.sibon@mcgill.ca and 14-3-3 CSF protein was positive. The patient died 1 month later. Brain examination confirmed the diagnosis of sporadic Creutzfeldt-Jakob disease (CJD) (figure).

Usually hyperintense changes in the striata and cerebral cortices at diffusion-weighted imaging, low apparent diffusion coefficients, and progressive or constant lesional distribution are characteristic of CJD. ${ }^{1}$ Our report suggests that CJD can radiologically mimic reversible posterior leukoencephalopathy. ${ }^{2}$

1. Murata T, Shiga Y, Higano S, Takahashi S, Mugikura S. Conspicuity and evolution of lesions in Creutzfeld-Jakob disease at diffusion weighted imaging. AJNR Am J Neuroradiol 2002;23:1164-1172.

2. Covarrubias DJ, Luetmer PH, Campeau NG. Posterior reversible encephalopathy syndrome: prognostic utility of quantitative diffusionweighted MR images. AJNR Am J Neuroradiol 2002;23:1038-1048. 


\section{Neurology}

\section{Creutzfeldt-Jakob disease mimicking radiologic posterior reversible leukoencephalopathy}

I. Sibon, A. Foubert, P. Menegon, et al. Neurology 2005;65;329

DOI 10.1212/01.wnl.0000175231.07913.e2

This information is current as of July 25, 2005

\section{Updated Information \&} Services

Supplementary Material

References

Permissions \& Licensing

Reprints including high resolution figures, can be found at: http://n.neurology.org/content/65/2/329.full

Supplementary material can be found at: http://n.neurology.org/content/suppl/2007/04/02/65.2.329.DC1

This article cites 2 articles, 0 of which you can access for free at: http://n.neurology.org/content/65/2/329.full\#ref-list-1

Information about reproducing this article in parts (figures,tables) or in its entirety can be found online at:

http://www.neurology.org/about/about_the_journal\#permissions

Information about ordering reprints can be found online:

http://n.neurology.org/subscribers/advertise

Neurology ${ }^{\circledR}$ is the official journal of the American Academy of Neurology. Published continuously since 1951, it is now a weekly with 48 issues per year. Copyright . All rights reserved. Print ISSN: 0028-3878. Online ISSN: 1526-632X.

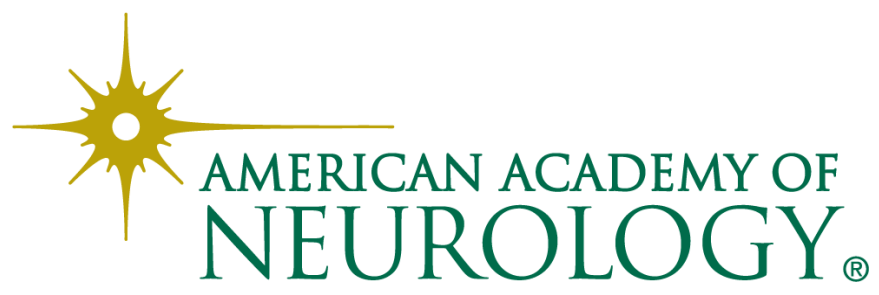

